\title{
PSYCHOLINGUISTIC PECULIARITIES OF UNDERSTANDING THE GRAMMATICAL MEANING OF PHRASES AND ITS USE IN SPEECH OF THE SENIOR PRESCHOOL CHILDREN
}

\author{
Larysa Kalmykova \\ Pereiaslav-Khmelnytskyi Hryhorii Skovoroda State Pedagogical University, Ukraine \\ Nataliia Kharchenko \\ Pereiaslav-Khmelnytskyi Hryhorii Skovoroda State Pedagogical University, Ukraine \\ Inna Mysan \\ Pereiaslav-Khmelnytskyi Hryhorii Skovoroda State Pedagogical University, Ukraine \\ Nataliia Rudkivska \\ Pereiaslav-Khmelnytskyi Hryhorii Skovoroda State Pedagogical University, Ukraine
}

\begin{abstract}
Aim: to investigate the state of development of the operations to understand the grammatical meaning of phrases and its use in the speech of senior preschool children.

Research procedure. The technique of "Comprehension of phrases" (Luria, 1998) was used to study the state of understanding by children of the grammatical meaning of different kinds of phrases. The state of the development in children of intra-speech operations related to semantic syntax and choice of linguistic meanings was investigated. The method of "Making up stories, descriptions, and reflections" was used to study the ability of children to use phrases in the process of constructing texts.

Results. The multilevelled state of the development in children of the operations of understanding the meanings of phrases and its use in speech, which is conditionally fixed in the form of 4 levels: high, sufficient, medium, low was revealed. It is established that both the operations of understanding the grammatical meaning of phrases and the operations of the use of phrases in a verbal speech in senior preschoolers are at the stage of its development. It has been revealed that children understand much more grammatical meanings of phrases than they use in oral speech. The expression in a speech of the relationships existing in the real (surrounding) reality through phrases is a much more complicated speech operation for children than an understanding of the grammatical meanings of these phrases.
\end{abstract}

Keywords: children of the pre-school age, speech, understanding of phrases, utterance of phrases.

\section{Introduction}

L.S. Vygotskyi (2011) noted that the speech meanings include both acts of generalization as a result of the psychic reflection of the reality, and acts of 
communication as fragments of human interaction with society. In this regard, the extremely important condition for the development of a linguistic personality is "the acquisition by a child of the ability to understand oral utterance through the formation not only of a personal meaning but also mastery of the system of linguistic values that "stand" behind the units of the language" (Kharchenko, 2016). At the same time, an equally important condition for becoming a linguistic personality is the development in children of the ability to express themselves clearly to others, to sound their thoughts, desires, intentions and feelings in the oral speech. In the implementation of these conditions, an important role plays the mastery by children of such a small syntactic unit as a phrase, the building material with a help of which develop both the understanding of speech (the connections and relationships between objects and phenomena of the real reality) and speaking (verbal expression of connections and relationships between the objects and phenomena of the real reality in various statements) (Kalmykova, 2016).

A phrase is a nominative unit, one of the important means of a lexicogrammatical combination of words in speech. They have grammatical meaning, express logical connections and relationships that exist between objects and phenomena of the real reality, and specify the meaning of words (Kalmykova, 2003, 2008). It is known that a child assimilates grammatical meaning twice in his life. For the first time, when inadvertently, involuntarily he correlates the heard and spoken images of the language signs with reality, its objects, phenomena, connections and relationships between them. Therefore, to associate a phrase with the objectively existed logical links and relationships that take place in the surrounding world means to understand the grammatical meaning. But such understanding of the grammatical meaning of phrases is intuitive and subconscious. It is mastering by a child at the level of intuition (that is to understand the content of information encoded in the phrase) is possible because the child has sensated, perceived, experienced phenomena or relationships between them that correspond to the designated units of language. Only in the process of active reflection of reality and active communication in child arise the understanding of language and the ability to express in the individual speech the own intentions, desires, aspirations, emotions, dreams, creative fantasies and plans (Fedorenko et al., 1984). Secondly, the child learns the grammatical meaning of phrases at school, when the initial awareness of such correlation begins and the necessity for abstraction and objectification of the awareness arises; the perception of a linguistic sign (unit), the selection of a linguistic sign and its grammatical meaning as a linguistic phenomenon, as a linguistic reality, as a metamorphic language (Kalmykova, 2017, 104-105). 
Therefore, the understanding by children of the grammatical meaning of phrases is:

1) an indicator of the development of child's speech and thinking (speech and thinking operations on the unintentional, involuntary, unconscious correlation of this unit of language with certain connections or relationships between objects and phenomena of the real reality that prove the comprehension of the content and perfection of transformations of the grammatical meaning of a phrase into the individual sense);

2) an indicator of the child's ability to use this language unit while speaking.

The purpose of the article is to present the results of an experimental study aimed at identifying of psycholinguistic peculiarities of understanding the grammatical meaning of phrases and its use in a speech by senior preschoolers.

\section{Methods and Techniques of the Research}

In the experimental study, the following methods were used, such as: interviewing of children, recording of their statements on a voice recorder, conversations with children; ascertaining experiment - for carrying out the procedure of interrogation and recording of qualitative characteristics of the state of development in children of the operations of understanding the grammatical meaning of phrases of different types and its use in oral speech; discourse analysis of children's utterances to obtain authentic information about children's ability to use certain types of phrases; content analysis; quantification and linguistic methods - for quantitative expression of qualitative signs of understanding the meaning of phrases in senior preschoolers.

Participants. In the experiment took part 378 preschoolers (5.0-5.5 years) attending pre-school educational establishments of Ukraine. Before the study, permission was obtained from the parents of children who participated in the experiment. All parents were introduced to the purpose of the study, its procedure and program.

Experiment procedure. To study the psycholinguistic peculiarities of understanding the grammatical meaning of phrases in the experiment, the technique "Understanding of phrases" was used (Luria, 1998). It aimed to identify the state of the development of intra-speech operations of semantic syntax and the choice of linguistic meanings in senior preschool children. Detection of the levels of understanding by children of phrases grammatical meaning was determined by such a major criterion as meaningfulness. Comprehension in the formulation of T.M. Ushakova is "the thought, reasonableness, ... presence in the subjective sphere of some kind of experience, <...> that captures the "correctness", 
Kalmykova et al., 2020. Psycholinguistic Peculiarities of Understanding the Grammatical Meaning of Phrases and Its Use in Speech of the Senior Preschool Children

"normality" of the course of events and being of phenomena, or their deviation from this norm" (Ushakova, 2004, 66-67). The levels of comprehension of the grammatical meaning of phrases with corresponding qualitative characteristics were determined.

The introduction of the method was in the form of a game "Explain to the Stranger what the statement means". The psychologist suggested the children listen to the expressions and explain how they understand them. The child's explanations were recorded in the minutes and evaluated with the appropriate scores.

Syntax constructions with different types of grammatical relationships were used, namely:

1) Substantive without prepositions in genetive case which express attributive relationships - adjuncts (lyst druha, promin sontsia, krylo litaka, hilka buzku, kryshka hlechyka).

2) Substantive with prepositions " $i z$ " ("zi") in genetive case, which express the origin relationships (vaza zi skla, hlechyk iz hlyny, koshyk iz lozy, med iz hrechky, chainyk iz farforu).

3) Substantive with preposition " $z$ ", which express the relationships of separation (zirka z neba, sik z berezy, knyzhka z biblioteky, riadky z virshiv).

4) Substantive in genetive case, combined by the prepositions "vid" to express the relationships of separation (ruchka vid dverei, lystochok vid kvitky, rul vid velosypeda, kryshka vid chainyka, skorynka vid khliba).

5) Adjective without prepositions, which express the relationships of characteristics (farforova tarilka, opale lystia, chainyi serviz, berezovyi hai, derev'ianyi stil).

6) Verbal with prepositions "vid", "cherez", which express the relationships of reason (padaie vid utomy, ne chytav cherez brak chasu, radiie vid nahorody, khvyliuietsia cherez nespodivanku, ne pryishov cherez khvorobu).

7) Verbal without prepositions in the accusative case, which express the relationships of location (bihty dorohoiu, khodyty lisom, yty polem, plysty richkoiu, strybaty stezhkoiu). 35 phrases were suggested to listen (5 phrases of each type).

Responses were rated on a three-point scale from 0 to 2 points:

2 points - the child correctly interpreted the phrase meaning («Lyst druha» - «Lyst vid druha»; «Lyst vidmoho druha»; «Vaza zi skla»«Skliana vaza»).

1 point - the child misinterpreted the phrase meaning («Lyst druha» «Tse lyst druha»; «Hilka buzku» - «Vona roste i yii mozhna zlamaty»). 
0 points - the child did not communicate with the experimenter and did not explain the content of phrase.

The maximum number of points according to the method "Understanding of phrases" - 70 points.

State of the operations development on understanding the meaning of phrases:

60-70 points - fully developed of the operations.

49-59 points - partially developed of the operations.

28-48 points - minimally developed of the operations.

$0-27$ points - undeveloped of the operations.

To investigate the ability of children to use the phrases, the following speech tasks were offered to them:

1) Make up a story on "How I spent the day off";

2) Build the reasoning "Why the fox is called cunning?"

3) Describe the picture "Kids' Winter Fun”. Children's statements were analyzed in terms of what phrases children use to express the connections and real-life relationships that are reflected in speech. For each type of relationship correlated with a particular phrase, 1 point was awarded. There were recorded the phrases in which children made mistakes in their use or experienced difficulties in the process of their construction. The sum of the points scored indicated a certain level of the development of children's syntactic structure of speech.

\section{Results}

While analyzing the children's interpretation according to the method "Undersatnding of phrases", it was found that the vast majority of children have underdeveloped operations on understanding the meaning of all kinds' phrases. None of the preschoolers could correctly decode the grammatical forms offered for interpretation, in particular deciphering of the meaning of substantive phrases in the genitive case with the preposition "vid", which express the relationship of separation.

The phrase was considered correctly decoded when the child revealed its substantive content (i.e. a fragment of the situation encoded in grammatical form) in a way of its transforming into another grammatical form while preserving the content of the information contained in the listened expression.

Here are the examples of correctly "decrypted" phrases.

1. Substantive phrases expressing attributive relationship (affiliations): «Lyst druha» («Tse lyst moho druha», «Druh napysav lyst», «Lyst napysav druh», «Lyst, shcho yoho napysav druh»). 
Kalmykova et al., 2020. Psycholinguistic Peculiarities of Understanding the Grammatical Meaning of Phrases and Its Use in Speech of the Senior Preschool Children

2. Substantive phrases with prepositions in genetive case expressing the relationship of origin:

1. «Vaza zi skla» («Tse vaza, shcho yii zrobyly iz stikla»).

2. «Hlechyk iz hlyny» («Hlynianyi hlechyk»).

3. «Sik z berezy» («Berezovyi sik»).

4. Adjective phrases without prepositions expressing the relationship of sign:

1. «Berezovyi hai» («Tse hai z berezamy»).

2. «Derev'ianyi stil» («Tse stil iz dereva»).

3. «Opale lystia» («Lystia vpalo na zemliu», «Lystia opalo z dereva»). 4. «Dubovyi lis» («Tse lis, de v nomu rostut duby»).

4. «Derev’ianyi stil» («Tse takyi stil, shcho vin zdielanyi z dereva»).

5. «Kvituchyi sad» («Tse sad, i v nomu rostut kvity»).

6. «Osinnii doshch» («Tse doshch ide osinniu»).

5. Verbal phrases with prepositions "vid", “cherez" expressing the relationship of reason:

1. «Padaie vid utomy» («Vtomyvsia», «Sylno vtomyvsia $i$ toho padaie», «Koly liudyna vtomylasia»).

2. «Ne pryishov cherez khvorobu» («Bo vin khvoryi», «Zakhvoriv $i$ ne pryishov», «Zakhvoriv i ne zmih nikudy ity», «Zakhvoriv»).

3. «Ne prochytav cherez brak chasu» («Buv zainiatyi»).

4. «Radiie vid nahorody» («Radyi, shcho yoho nahorodyly»).

5. «Mokryi vid rosy» («Bo zranku khodyv po travi, a na nii bula rosa i namochyv nohy»).

6. «Khvyliuietsia cherez nespodivanku» («Ne chekav chohos, ale tse stalosia»).

We considered to be false the interpretations in which children revealed the meaning of phrases in such ways.

1. Repeated either stimulating phrase, or a word that is a part of the perceived grammatical construction. For example:

1. «Lyst druha»- «Tse lyst druha», «Tse lyst».

2. «Zirka z neba» - «Tse koly zirka z neba», «Zirka».

Decoded the meaning of phrases based on the formation of associative syntagmatic relationships through:

a) isolation of the sign of denotatus action. For example:

1. «Promin sontsia»-«Hriie ditei».

2. «Hilka buzku» - «Vona roste i yii mozhna zlamaty, a todi posadyty», «Roztsvitaie vesnoiu».

3. «Hlechyk iz hlyny» - «Vypaliuiut».

4. «Koshyk iz lozy»-«Pletut», «Koshyk iz lozy zaplitaiut». 
5. «Sik z berezy» - «Zbyraiut vesnoiu», «Mozhna pyty», «Vylyvaietsia».

6. «Zirka z neba»-«Padaie», «Padaie na zemliu».

7. «Kvity z pivnochi» - «Zav'ianuly».

8. «Ruchka vid dverei»-«Oblamalasia».

9. «Lystochok vid kvitky» - «Roste», «Odpav», «Upav na zemliu»;

b) through predicting intentions, goals. For example:

1. «Ruchka vid dverei» - «Shchob mozhna prychepyty», «Shchob vidkryvaty», «Shchob vidkryvaty i zakryvaty dveri».

2. «Lystochok vid kvitky» - «Mozhna zirvaty».

3. «Rul vid velosypeda»- «Shchob velosyped mih poikhaty», «Shchob mozhna todi yikhaty na velosopedi».

4. «Skorynka vid khliba» - «Shchob mozhna yii z'isty».

5. «Farforova tarilka» - «Mozhna rozbyty», «Shchob mozhna bulo yisty z nei»;

c) through association with the appointment of denotatus. For example:

1. «Vaza zi skla» - «Shchob kvity ne padaly».

3. «Hlechyk iz hlyny» - «Shchob vin buv tverdyi».

4. «Derev'ianyi stil» - «Shchob na nomu chytaty»;

d) through association with the signs of quality, color, length, size, taste. For example:

1. «Vaza zi skla»-«Prozrachna».

2. «Hilka buzku»-«Dovha».

3. «Zirka z neba»-«Zirky buvaiut hariachi i kholodni».

5. «Lyst druha»-«Bilyi lystok».

6. «Promin sontsia»-«Zhovtyi».

7. «Med iz hrechky» - «Lypka hrechka», «Med solodkyi»;

e) through association with place (location). For example:

1. «Farforova tarilka»-«Stoit u mikrovolnovtsi».

2. «Kryshka vid chainyka»- «Kryshka zverkhu»;

f) through making comparisons. For example:

1. «Krylo litaka» - «Iak u ptashky».

2. «Zirka z neba»- «Iak sontse».

3. «Sik z berezy»-«Iak voda».

4. «Hlechyk iz hlyny» - «Hlyna, yak plastilin»;

g) explained the meaning of phrases through random association with other concepts based on phonetic similarity. For example:

1. «Kvity z pivnochi» - «Tse kvity, shcho tsvitut, no tilky polovynu nochi», «Kvity, shcho tsvitut vnochi», «Kvity rostut nochchiu», «Tse koly nich», «Nichni kvity». 
Kalmykova et al., 2020. Psycholinguistic Peculiarities of Understanding the Grammatical Meaning of Phrases and Its Use in Speech of the Senior Preschool Children

2. «Opale lystia»-«Lystia paliat», «Lystia na kostor padaie i palyt», «Bo yoho zapalyly», «Tse vono zghorile»;

h) through association with life situations (experience). For example:

1. «Podarunok vid mamy» - «Radist ditiam», «Vona potsiluie nas», «Siurpryz», «Shchastia u tebe».

2. «Knyzhka z biblioteky» - «Dolzhna buty v bibliotetsi bez hroshei», «Daietsia na odyn chy dva dnia», «Ia iz mamoiu brala chytaty».

3. «Knyha tovarysha»-«Dav meni pochytaty».

According to the results of diagnostics, 4 levels of the development of children's ability to understand the grammatical meaning of phrases were recorded: high, sufficient, medium, low. Quantitative characteristics of the state of development in children of the operations of understanding the meaning of phrases are reproduced in the comparative table (see Table 1).

To a high level of the development of operations of understanding the meaning of phrases (60-70 points) was not attributed any child. It was assumed that children of this level would have fully developed operations to select language values and semantic syntax; they will be able to understand the substantive content of grammatical constructions (a fragment of objective reality encrypted in a perceived grammatical structure).

To a sufficient level of the development (49-59 points) was attributed 9.5\% $(n=36)$ of children who had partially developed operations appropriate for selection of the language values and semantic syntax; they are capable of deciphering the substantive content of phrases of the various kinds but have difficulties in decoding the meaning of substantive phrases expressing the relationship of separation.

To an average level of the development (28-48 points) was attributed 33.9\% $(n=128)$ of children with minimal development of understanding the meaning of phrases; they decipher the substantive content of only certain types of phrases (mainly substantive in the genitive case, which express the relationship of occurrence and adjective without prepositions that express the relationship of characteristics); other types of phrases are mistakenly decoded by children (through the formation of various associative relationships).

To a low level of the development (0-27 points) was attributed to $56.6 \%$ $(n=214)$ of children who have underdeveloped operations of understanding the meaning of phrases; they cannot decipher the substantive content of the perceived constructions. In trying to decode the meaning of a phrase, children usually either repeated the stimulus phrase completely, or the word of the phrase, or interpret its meaning through the formation of various connections. To this level were also included the children who did not interact with the experimenter.

Observations on children's utterances (narratives, descriptions, reflections) and its analysis have shown that without organized language training, the real 
possibilities of a five- or six-year-old child to use phrases are very limited. The arsenal of phrases available in the language experience of a senior preschooler is still very poor. His speaking skills are deficient. It impairs the cognitive activity, limits, narrows the boundaries of communication, and inhibits the timely growth of the individual. In order to express the relationship of cause, purpose, method of action, children willingly use complex sentences, but they do not know how to use certain phrases. The girl says, "I got a bruise because I was hit", though she might say more simply, "I have a bruise from a blow".

The means of expression of the defining relationships that are not acquired by children without special training include phrases based on the grammatical relationship of management. These are, for example, those that mean: a sign (a friend's book, a hare's footprints); the subject of action (singing of the nightingale); the carrier of the sign (kindness of the mother, the whiteness of the snow); defining relationships (marble walls; fish under the marinade) and so on. To convey the additional relationships, the children are more likely to use a direct object, expressed by the accusative case (took a pencil), or indirect (to help mom), and also use an instrumental case (wiped with a towel, went with the dog) with or without the pronoun.

Diagnosis of the state of development of the syntactic operations for constructing stories, considerations and descriptions made it possible to distinguish four levels of the development of operations for constructing phrases (see Table 1).

To a high level of the development of operations to use the phrases (1520 points) was not attributed any child.

To a sufficient level of the development of these operations (11-15 points), the children were not attributed also.

To the average level of the development of operations to use in speech phrases (6-10 points) was attributed $43.6 \%(n=165)$ of children who can use verbal phrases such as "bought a ticket", "went on a train”. Very seldom they build substantive phrases such as: "blue ball", "little fungus". These children have difficulties in expressing attributive, causal, temporal, behavioral, and other relationships throuth phrases.

To a low level of the development of operations to use phrases ( $0-5$ points) was attributed $56.4 \%(n=213)$ of preschoolers who use in their speech mostly verbal phrases of place (location) and direction ("went to the woods", "walked around the house").

Quantitative characteristics of the state of development in children of the operations of understanding the meaning of phrases is reproduced in the comparative table (see Table 1). 
Kalmykova et al., 2020. Psycholinguistic Peculiarities of Understanding the Grammatical Meaning of Phrases and Its Use in Speech of the Senior Preschool Children

Table 1 Levels of the development in children the ability to understand the grammatical meaning of phrases and to use them in oral language

\begin{tabular}{|c|c|c|c|c|}
\hline \multirow{2}{*}{$\begin{array}{c}\text { Levels of understanding the } \\
\text { meaning of phrases and their } \\
\text { use in speech }\end{array}$} & \multicolumn{2}{|c|}{$\begin{array}{c}\text { Understanding of the } \\
\text { grammatical meaning of phrases }\end{array}$} & \multicolumn{2}{|c|}{ Use of phrases } \\
\cline { 2 - 5 } & $\%$ & $\mathrm{~N}$ & $\%$ & $\mathrm{~N}$ \\
\hline High & - & - & - & - \\
\hline Sufficiant & 9,5 & 6 & - & - \\
\hline Medium & 33,9 & 128 & 43,6 & 165 \\
\hline Low & 56,6 & 214 & 56,4 & 213 \\
\hline
\end{tabular}

In figure 1 is presented the comparison of data according to the levels of development of the operations of phrases comprehension and their use in speech of the senior preschoolers (Fig. 1).

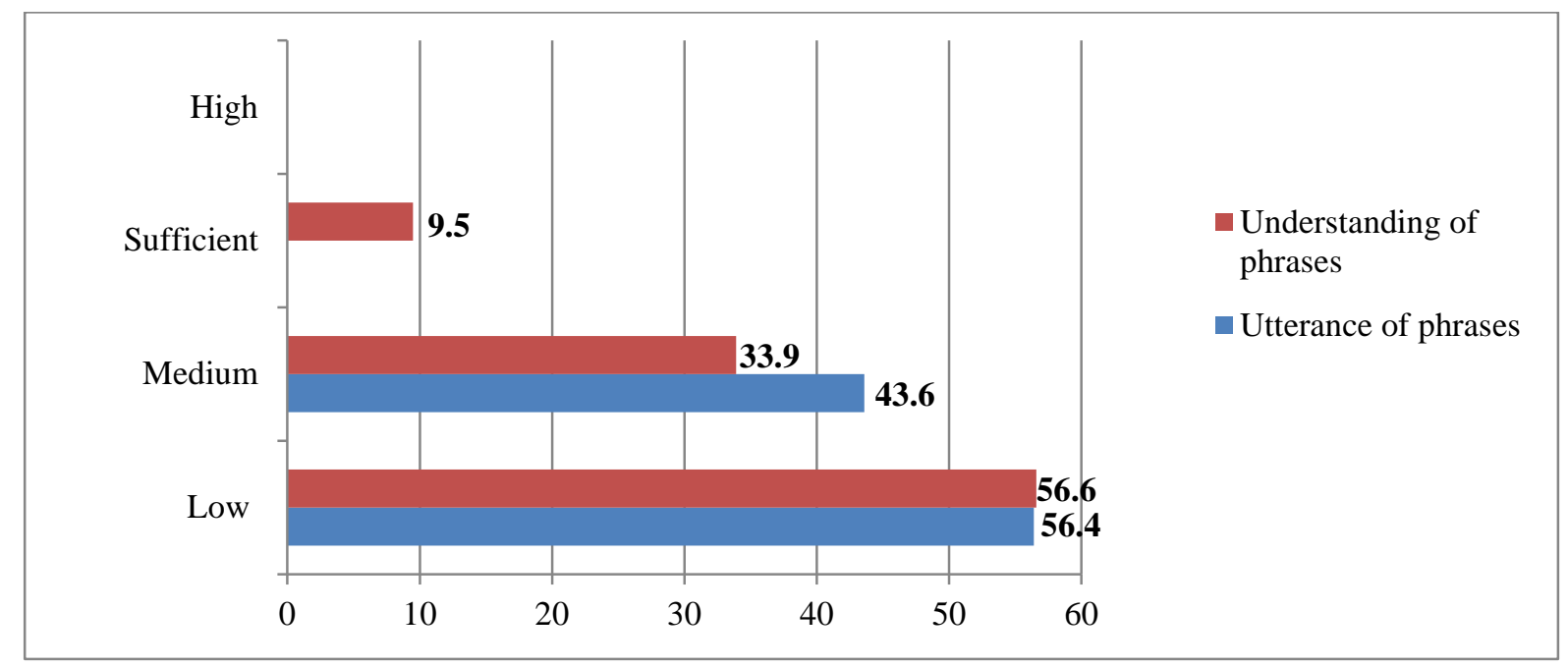

Figure 1 Levels of the development of operations of understanding the phrases and its use in speech of children of the senior preschool age

The experiment made it possible to establish that both the operations of understanding the grammatical meaning of phrases and the operations of the use of phrases in oral speech of the senior preschool children are at the stage of development.

\section{Conclusions}

The experiment made it possible to establish that the operations of understanding the grammatical meaning of phrases in children of the senior preschool age require further development. The reasons for non-formation of the 
operations of understanding the meaning of phrases in children, as we see are related to underdevelopment of following operations:

1) semantic syntax and choice of linguistic values;

2) separation of connections and relationships between objects and phenomena of the real reality;

3) correlation and comprehension of the heard phrase with the system of connections and relationships of extralinguistic (real) reality reproduced in the nuclear grammatical construction;

4) simultaneous analysis and synthesis.

The analysis of the children's utterances who participated in the experiment shows that purely childish, monotonous means of expressing syntactic relations dominated in them; the utterances have many syntax errors in the management and coherence of words. Significant difficulties arise in constructing sentences that contain more than 4 words; children have not mastered the rules for constructing substantive and other kinds of phrases, etc.

Our research has shown that the ability to use phrases in constructing utterances does not form self-sufficiently. Communication alone does not yet create the necessary linguistic environment that is capable of assimilating by a child with sufficient linguistic material and encouraging it to master the language. Most of the preschoolers require skilled psycholinguistic help from the educator and systematic training, purposeful formation in them of the syntactic structure of speech, since its formation is a prerequisite for mastery by children of coherent speech, and skills for communication. Among them are the following skills: to choose the appropriate phrases when they express their thoughts, reproduce what they saw, heard, experienced, wished, etc.; to choose the syntax options from the number of synonyms according to a particular communication situation; to find appropriate syntax constructions for expressing different relationships (target, causal, attributive, circumstantial, temporal, spatial, etc.) in the process of creating stories, descriptions, considerations, etc.

It has been experimentally found that children understand a much greater number of grammatical meanings of phrases than they use in oral speech. Therefore, expressing in the speech of the relationships existing in the real (surrounding) reality employing phrases is a much more complicated speech operation for children than understanding the grammatical meanings of these phrases.

\section{References}

Fedorenko, L.P., Fomicheva, G.A., Lotarev, V.K., \& Nikolaicheva, A.P. (1984). Metodika razvitiya rechi detej doshkolnogo vozrasta [Methods of speech development in preschool children]. Moscow: Prosveshenie [in Russian]. 
Kalmykova et al., 2020. Psycholinguistic Peculiarities of Understanding the Grammatical Meaning of Phrases and Its Use in Speech of the Senior Preschool Children

Kalmykova, L.O. (2003). Formuvannja movlennevih umin $i$ navichok $u$ ditej: psiholingvistichnij ta lingvometodichnij aspekti [Formation of speech skills in children: psycholinguistic and lingomechanical aspects]. Kyiv: NMCVO [in Ukrainian].

Kalmykova, L.O. (2008). Psihologiya formuvannya movlennevoyi diyalnosti u ditey doshkilnogo viku [Psychology of formation the speech activity in preschool children]. Kyiv: Feniks [in Ukrainian].

Kalmykova, L.O. (2016). Pro stan rozvitku movlennja jak dijalnosti u ditej p'jati rokiv [On Status of Speech Developmen as an Activity of Five Years Old Children]. Psiholingvistika - Psycholinguistics, 19(1), 84-98 [in Ukrainian].

Kalmykova, L.O. (2017). Perspektivnist i nastupnist $v$ navchannimovi j rozvitku movlennya ditej doshkilnogo i molodshogo shkilnogo viku: psiholingvistichnij i lingvometodichnij vimiri [Perspective and Continuity in Language Learning and Language Development in Preschool and Primary School Children: Psycholinguistic and Linguomethodological Dimensions]. Kiyiv: Vidavnichij Dim «Slovo» [in Ukrainian].

Kharchenko, N.V. (2016). Rozvitok movnoi osobistosti doshkilnika v konteksti audijuvannja: avtorskij pidhid [Development of Preschooler's Language Identity in the Context of Listening: Auther’s Approach]. Psiholingvistika - Psycholinguistics, 19(1), 183-197 [in Ukrainian].

Luria, A.R. (1998). Yazyk i soznanie [Language and Cognition]. E.D. Khomskaya (Ed.). Rostov n/D: Feniks [in Russian].

Ushakova, T.N. (2004). Rech: istoki i principy razvitiya [Speech: the Origins and Principles of the Development]. Moscow: PERSE [in Russian].

Vygotskiy, L.S. (2011). Myshlenie i rech [Thought and Language]. Moscow: AST: Astrel [in Russian]. 